\title{
Fruit Set as an Index for Harvesting Edward Mangos $^{1}$
}

\author{
Hugo L. Cancel and Teresa García de Pérez ${ }^{2}$ \\ ABSTRACT
}

Fruit set was used as an index for harvesting mangos of the Edward variety. Fruit setting date was determined for each tree in order to establish one harvesting date for the total fruit production of that tree. Fruits were classified according to size and ripeness. At 15 weeks after fruit set there were a large number of fruits with the maximum diameter of 3 in or larger. These fruits were in a mature but green stage. A longer delay of harvesting after fruit set gave fruits of a more advanced stage of ripeness. Although these fruits could be used for immediate consumption, they can not withstand too much handling or prolonged storage.

\section{INTRODUCTION}

Mango (Mangifera indica L.) is one of the important fruit crops in tropical regions. Mangos are usually harvested at a stage of ripeness based only on the judgment of an experienced picker.

The stage of maturity and ripeness at harvesting are of great importance, since they determine the quality of the fruit and its products.

Many physical indices have been studied as nondestructive measures to ascertain the maturity and ripeness of different mango varieties. ${ }^{3,4}$ Unfortunately, criteria useful for one mango variety may not be valid for others.

The main purpose of this investigation was to study the number of days after fruit set as an index for harvesting Edward mangos.

\section{MATERIALS AND METHODS}

Mangos of the Edward variety were used. The orchard is located at the Fortuna Substation on the southern coast of the Island. The trees are at least 15 years old and are in full production. These are scattered throughout a 27 -acre plot of different varieties of mango. The trees were selected at random, excluding the very small or diseased ones.

Fruit set date was taken when the terminal flowers of the panicles

'Manuscript submitted to Editorial Board April 28, 1978.

${ }^{2}$ Assistant Food Technologist and Research Assistant, respectively, Food Technology Laboratory, Agricultural Experiment Station, Mayagüez Campus, University of Puerto Rico, Río Piedras, P.R.

${ }^{3}$ Krishnamurthy, Shantha and Subramanyam, H. 1970. Respiratory, climacteric and chemical changes in the mango fruit (Mangifera indica L.) J. Am. Soc. Hort. Sci., 95 (3), 333-337.

4 - and - 1973. Pre- and postharvest Physiology of the mango fruit: a review. Trop. Sci., 15: 167-193. 
showed a higher percentage of very small fruits. Therefore, the fruit set date represents the average fruit set for each individual tree.

Harvesting was done by hand, all the mangos of each tree collected at one time. The production of fruits per tree varied from 134 to 586, with a mean of 311. The first harvest was at the eleventh week after fruit set. Thereafter, there were weekly pickings until the eighteenth week.

During the experimental period the total rainfall was $9.88 \mathrm{in}$. To compensate for insufficient rainfall during dry periods, drip irrigation was applied. The air temperature during this same period varied between 89.3 to $65.5^{\circ} \mathrm{F}$, with a mean of $77.8^{\circ} \mathrm{F}$.

Fruits were classified by size with a series of graders. These graders had variable size slots so they could retain or let pass fruits, depending on their major diameter. The size gradings used were No. 1, fruits with a diameter less than $2 \frac{1}{1 / 2}$; No. 2 , fruits with a diameter larger than $2^{1 / 2} 2^{\prime \prime}$ but smaller than $3^{\prime \prime}$; No. 3, fruits with a diameter larger than $3^{\prime \prime}$ but smaller than $31 \frac{1}{2 \prime}$; No. 4, fruits with a diameter larger than $31 / 2^{\prime \prime}$.

TABLE 1.-Variations in the size of the Edward mangos with respect to the time after fruit set

\begin{tabular}{ccccc}
\hline \multirow{2}{*}{$\begin{array}{c}\text { Time after fruit } \\
\text { set }\end{array}$} & \multicolumn{4}{c}{ Fruits of each size } \\
\cline { 2 - 5 } Weeks & No. 1 & No. 3 & No. 4 \\
\hline 11 & 57.6 & 42.4 & 0 & 0 \\
12 & 70.1 & 29.9 & 0 & 0 \\
13 & 32.8 & 56.5 & 10.7 & 0 \\
14 & 6.5 & 48.2 & 45.3 & 0 \\
15 & 0 & 20.3 & 73.1 & 6.6 \\
16 & 2.8 & 20.7 & 73.4 & 3.1 \\
17 & 0 & 0 & 77.8 & 22.2 \\
18 & 0 & 7.8 & 73.8 & 18.4 \\
\hline
\end{tabular}

The degree of ripeness was judged visually by the peel color. The ripeness index used was the following: $\mathrm{A}$, green, the peel a deep green color; B, green-yellow, the peel turning yellow but more than $50 \%$ was green; C, yellow-green, more than $50 \%$ yellow but with green areas; D, yellow, peel yellow with no green.

\section{RESULTS AND DISCUSSIONS}

This study of the Edward mango revealed that the only flowers that bore fruits were those toward the terminal end of the panicle. Fruit set was ascertained by observing on the tree the terminal flowers of the panicles. Each panicle bore one to three mangos until harvesting time.

Table 1 shows the variation between fruit sizes at different intervals from the time of fruit set determined for the whole tree. The data 
TABLE 2.-Ripeness distribution of different sizes of the Edward mangos with respect to the elasped time since fruit set

\begin{tabular}{|c|c|c|c|c|c|c|c|c|c|c|c|c|c|c|c|c|}
\hline \multirow{3}{*}{$\begin{array}{l}\text { Time after } \\
\text { fruit set }\end{array}$} & \multicolumn{16}{|c|}{ Fruit Ripeness and Size } \\
\hline & \multicolumn{4}{|c|}{ Green (A-stage) } & \multicolumn{4}{|c|}{ Green-Yellow (B-stage) } & \multicolumn{4}{|c|}{ Yellow-Green (C-stage) } & \multicolumn{4}{|c|}{ Yellow (D-stage) } \\
\hline & 1 & 2 & 3 & 4 & 1 & 2 & 3 & 4 & 1 & 2 & 3 & 4 & 1 & 2 & 3 & 4 \\
\hline Weeks & $\%$ & $\%$ & $\%$ & $\%$ & $\%$ & $\%$ & $\%$ & $\%$ & $\%$ & $\%$ & $\%$ & $\%$ & $\%$ & $\%$ & $\%$ & $\%$ \\
\hline 11 & 57.6 & 42.4 & - & - & - & - & - & - & - & - & - & - & - & - & - & - \\
\hline 12 & 70.1 & 29.9 & 一 & - & - & - & - & - & - & - & - & - & - & - & 一 & - \\
\hline 13 & 32.1 & 53.3 & 10.0 & - & 0.7 & 3.3 & 0.7 & - & - & - & - & - & - & - & - & - \\
\hline 14 & 6.5 & 41.7 & 41.7 & - & - & 5.6 & 0.9 & - & - & 0.9 & 2.8 & - & - & - & - & 一 \\
\hline 15 & - & 13.5 & 67.6 & 6.8 & - & 5.4 & 1.4 & - & - & - & - & - & - & 1.4 & 4.1 & - \\
\hline 16 & 2.8 & 13.9 & 62.8 & 2.8 & - & 1.8 & 3.3 & 0.3 & - & 2.5 & 4.3 & - & - & 2.5 & 3.0 & - \\
\hline 17 & - & - & 46.7 & 15.6 & - & - & 11.1 & 4.4 & - & - & 8.9 & 2.2 & - & - & 11.1 & - \\
\hline 18 & - & - & 30.3 & 5.4 & - & 3.5 & 17.1 & 3.8 & - & 2.5 & 15.1 & 9.2 & - & 1.8 & 11.3 & - \\
\hline
\end{tabular}


obtained shows that by the eleventh and twelfth weeks after fruit set, 58 and $70 \%$, respectively, of the fruits were less than $2 \frac{1}{2}$ in in diameter. The overall production during these time intervals was represented by fruits of less than 3 in in diameter.

It was observed that the fruits of this variety have a tendency to reach an average diameter of 3 to $31 / 2$ in or larger. According to the data the concentration of these fruit sizes began at the 14th week after fruit set. At this time $45 \%$ of the fruit had reached a diameter larger than $3 \mathrm{in}$. At the 15 th week there was an increase to $79.7 \%$, and at the 17 th week more than $90 \%$ of the fruits were larger than $3 \mathrm{in}$.

Table 2, shows that a greater proportion of fruits were 3 in or larger in diameter in the green or green-yellow stage of ripeness by the 15th week. By this time $75.8 \%$ were of a diameter larger than 3 in and had a green or green-yellow stage of ripeness. Only $4.1 \%$ were on the more advanced stages of ripeness. At the 18 th week the more advanced stages of ripeness increased to a total of $39.9 \%$.

Fruits harvested for the fresh market must be at a ripeness stage that can withstand the handling and shipping hazards. Fruits classified as green or green-yellow were firmer to the touch than those at the other two ripeness stages. Mangos at the former two ripeness stages had a better chance of withstanding shipping and handling, while the latter could be used for immediate sale.

From the data obtained it may be concluded the Edward mango trees could be harvested on a programmed basis, with fruit set as an index. Fruits harvested at the 15th or 16th week after fruit set are in an early stage of ripeness and may be used for storing or shipping, while fruits harvested at the 18th week after fruit set, which are in more advanced stage of ripeness, may be used for processing or immediate sale.

\section{RESUMEN}

Muchas investigaciones se han llevado a cabo para obtener un índice de cosecha del mangó. En este trabajo y usando los árboles de la variedad Edward, se han podido correlacionar el tamaño y la madurez de la fruta con la época de cuaje. EI tamano de la fruta varía, dentro de ciertos límites, desde la época de cuaje. Esta fecha da un índice para cosechar la fruta. Cuando la fruta ha obtenido un tamaño de $3^{\prime \prime}$ o mayor de diámetro está en buen estado de cosecho. Estos tamaños de frutas se obtienen en mayor concentración desde las 15 semanas desde la época de cuaje en adelante. Sin embargo no podemos dejar la fruta en el árbol por muchas semanas pues su madurez aumenta. Esto trae como consecuencia que las frutas maduras o casi maduras no toleren manipulación durante su distribucion y se echen a perder.

Por lo tanto se recomienda que, para esta variedad, las frutas que tengan un tiempo desde el cuaje de 15 a 16 semanas, sean cosechadas para usarse en almacenamiento o embarques, ya que pueden madurar y mejorar su calidad. Las frutas cosechadas después de las 18 semanas se pueden usar para el consumo inmediato o para procesarse. 